\title{
CHARACTERIZATION OF ZIGZAG PATTERNS ON THE SURFACE OF BOVINE SERUM ALBUMIN FILMS
}

\author{
D.M. Glibitskiy ${ }^{1}$, O.A. Gorobchenko ${ }^{2}$, O.T. Nikolov $^{2}$, A.V. Shestopalova ${ }^{1}$, \\ M.A. Semenov ${ }^{1}$ \\ ${ }^{I}$ O. Ya. Usikov Institute for Radiophysics and Electronics of the National Academy of Sciences of Ukraine, \\ 12, Acad. Proskura St., 61085, Kharkiv 61022, Ukraine \\ ${ }^{2}$ V.N. Karazin Kharkiv National University, 4 Svobody Sq., Kharkiv 61022, Ukraine \\ e-mail:_ima.glib@gmail.com \\ Submitted May 18, 2017 \\ Accepted June 1, 2017
}

Analysis of the patterns formed during the drying of biological fluids is employed for research and diagnosis in medicine and agriculture. Saline solutions of native proteins and DNA are characterized by zigzag patterns, which could be quantitatively described using the specific length of zigzags $\mathrm{L}_{\text {specific }}$. The aim of this study was to analyze a wide number of characteristics in order to identify those most sensitive to the effects of various physical and chemical factors on the protein structure. We examined the films prepared from salt solutions of bovine serum albumin (BSA) under varying conditions, viz.: a proportional change in the concentration of the components, substitution of $\mathrm{NaCl}$ with $\mathrm{NaF}$ and $\mathrm{NaBr}$, temperature treatment, gamma irradiation, and addition of trivalent iron and biologically active flavin mononucleotide. The results revealed that the distribution of zigzag segment lengths was approximately lognormal, and the distribution of angles between the segments was approximately logistic. Two parameters appeared to be the most informative, viz. the average length of the segments, mainly depending on $\mathrm{Cl}^{-}$concentration, and the number of segments, depending on: $\mathrm{Cl}^{-}$concentration, concentration of the non-aggregated (but not necessarily unfragmented) protein, and the excess concentration of ions and low molecular weight compounds.

KEY WORDS: BSA, film, zigzag patterns, texture, statistical distribution.

\section{АНАЛІЗ ХАРАКТЕРИСТИК ЗИГЗАГОПОДІБНИХ ПАТЕРНІВ НА ПОВЕРХНІ ПЛІВОК БИЧАЧОГО СИРОВАТКОГО АЛЬБУМІНУ Д.М. Глибицький ${ }^{1}$, О.О. Горобченко ${ }^{2}$, О.Т. Ніколов ${ }^{2}$, А.В. Шестопалова ${ }^{1}$, М.О. Семенов ${ }^{1}$ ${ }^{1}$ Інститут радіофізики та електроніки ім. О. Я. Усикова НАН України, вул. Ак. Проскури 12, м. Харків, 61085, Украӥна \\ ${ }^{2}$ Харківський національний університет ім. В. Н. Каразіна, пл. Свободи 4, м. Харків, 61022, Україна}

Аналіз патернів, що формуються при висиханні біологічних рідин, використовується для досліджень і діагностики в медицині і сільському господарстві. Для сольових розчинів нативних білків і ДНК характерні зигзагоподібні патерни, які можна кількісно описати за допомогою питомої довжини зигзагів $\mathrm{L}_{\text {specific. }}$ У даній роботі ми аналізуємо розширений ряд характеристик цих патернів з метою виявити найбільш чутливі до дії різних фізичних і хімічних факторів на структуру білка. Були розглянуті плівки, отримані з сольових розчинів бичачого сироваткого альбуміну (БСА) при пропорційній зміні концентрації компонентів, заміні $\mathrm{NaCl}$ на $\mathrm{NaF}$ i $\mathrm{NaBr}$, температурній обробці, гамма-опроміненні, а також додаванні тривалентного заліза і біологічно активної речовини - флавінмононуклеотида. Було визначено, що розподіл довжин сегментів зигзагів має близький до логнормального характер, а розподіл кутів між сегментами - близький до логістичного. Дані показали, що найбільш інформативними є два параметри: середня довжина сегментів, яка переважно залежить від концентрації $\mathrm{Cl}^{-}$, і кількість сегментів, яка залежить від концентрації $\mathrm{Cl}^{-}$, концентрації неагрегованого білка (але не обов'язково нефрагментованого), а також від надлишкової концентрації іонів і низькомолекулярних сполук.

КЛЮЧОВІ СЛОВА: БСА, плівка, зигзагоподібні патерни, текстура, статистичний розподіл.

(C) Glibitskiy D.M., Gorobchenko O.A., Nikolov O.T., Shestopalova A.V., Semenov M.A., 2017 


\author{
АНАЛИЗ ХАРАКТЕРИСТИК ЗИГЗАГОПОДОБНЫХ ПАТТЕРНОВ \\ НА ПОВЕРХНОСТИ ПЛЕНОК БЫЧЬЕГО СЫВОРОТОЧНОГО АЛЬБУМИНА \\ Д.М. Глибицкий ${ }^{1}$, О.А. Горобченко ${ }^{2}$, О.Т. Николов $^{2}$, А.В. Шестопалова ${ }^{1}$, М.А. Семёнов ${ }^{1}$ \\ ${ }^{I}$ Институт радиофизики и электроники им. А. Я. Усикова НАН Украины, \\ ул. Ак. Проскуры 12, г. Харьков, 61085, Украина \\ ${ }^{2}$ Харьковский национальный университет им. В.Н. Каразина, пл. Свободы 4, г. Харьков, 61022, Украина
}

\begin{abstract}
Анализ паттернов, формирующихся при высыхании биологических жидкостей, используется для исследований и диагностики в медицине и сельском хозяйстве. Для солевых растворов нативных белков и ДНК характерны зигзагоподобные паттерны, которые можно количественно описать с помощью удельной длины зигзагов $\mathrm{L}_{\text {specific }}$. В данной работе мы анализируем расширенный ряд характеристик этих паттернов с целью выявить наиболее чувствительные к действию различных физических и химических факторов на структуру белка. Были рассмотрены пленки, полученные из солевых растворов бычьего сывороточного альбумина (БСА) при пропорциональном изменении концентрации компонентов, замене $\mathrm{NaCl}$ на $\mathrm{NaF}$ и $\mathrm{NaBr}$, температурной обработке, гамма-облучении, а также добавлении трехвалентного железа и биологически активного вещества - флавинмононуклеотида. Было определено, что распределение длин сегментов зигзагов имеет близкий к логнормальному характер, а распределение углов между сегментами - близкий к логистическому. Данные показали, что наиболее информативными являются два параметра: средняя длина сегментов, которая преимущественно зависит от концентрации $\mathrm{Cl}^{-}$, и количество сегментов, которое зависит от концентрации $\mathrm{Cl}^{-}$, концентрации неагрегированного белка (но не обязательно нефрагментированного), а также от избыточной концентрации ионов и низкомолекулярных соединений.
\end{abstract}

КЛЮЧЕВЫЕ СЛОВА: БСА, пленка, зигзагоподобные паттерны, текстура, статистическое распределение.

Drying biofluids and saline solutions of biomolecules are known for their ability to form patterns on the substrate surface, the specific form of which depends, in particular, on the structural state of biomolecules [1-4]. This fact has found practical application in some research and diagnostic methods of medicine and agriculture: the study of the interaction of biomolecules [5], the diagnosis of the patient's blood condition [6-10], the analysis of the quality of wheat grains $[11,12]$ and carrot roots $[13,14]$.

An important factor determining the practical applicability of such methods is the ability to numerically characterize the patterns formed on the substrate. Such a numerical characteristic is useful for assessing the degree and nature of the changes in the test sample compared to the control.

Depending on the type of pattern or texture, various authors offered such evaluation criteria as: the number of optical density fluctuations [9] or the brightness distribution of the digital image [11] in circular sections of different diameters; the fractal dimension of Minkowski [5] and the local connected fractal dimension of the image [12]; parameters of gray-scale histograms at several scales [13-15]; the structural and spectral characteristics of an image region as a function of time [10].

In previous studies we found that zigzag (hexagonal) patterns [16-19], similar to those observed in [20,21], are formed on films obtained from saline solutions of native DNA or protein. For a quantitative description of this type of texture, we introduced the value $\mathrm{L}_{\text {specific }}$, which corresponds to the total length of zigzag patterns per unit area. $\mathrm{L}_{\text {specific }}$ has random character due to the chaotic nature of the drying process and depends on the salt concentration, the biopolymer concentration, the conditions of solution preparation and drying (temperature, humidity, substrate material and roughness), as well as the properties of the biopolymer, salt and solvent.

As a result of significant physical or chemical influences that disrupt the structure of the biopolymer, zigzag patterns on the dried films are not formed $\left(\mathrm{L}_{\text {specific }}=0\right)$. However, it is often difficult to identify reliable differences between smaller levels of exposure due to a significant variance in the values of $\mathrm{L}_{\text {specific }}$ within the same dose of exposure $[17,18]$. In this regard, the purpose of the current study was to analyze the extended series of characteristics 
of zigzag patterns on the surface of BSA films, including the parameters of their statistical distributions, and to find which ones are the most sensitive to the action of various physical and chemical factors.

\section{MATERIALS AND METHODS}

The analysis was carried out on the basis of data obtained during the previous experiments $[18,19,22,23]$. The films were obtained from saline BSA solutions via vacuum drying at $40{ }^{\circ} \mathrm{C}$ in $20 \times 20 \times 1 \mathrm{~mm}^{3}$ glass cells. Each film was photographed (using a Meopta microscope and a Logicfox LF-PC011 webcam) in 100 positions uniformly distributed over the cell area, and segments of zigzag patterns were marked on each photograph (using custom software). The data was analyzed and plotted using numpy, scipy and matplotlib libraries.

\section{RESULTS AND DISCUSSION}

Zigzag patterns (Fig. 1) are presumably the result of crystallization in alternating crystallographic directions [20,24].

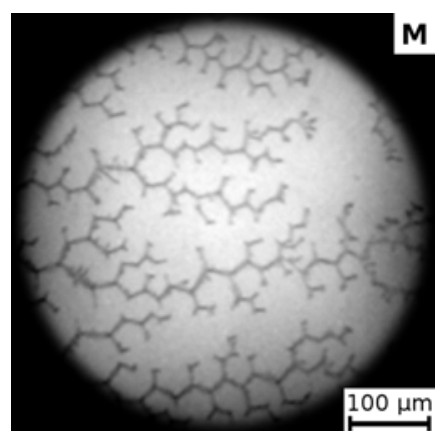

(a)

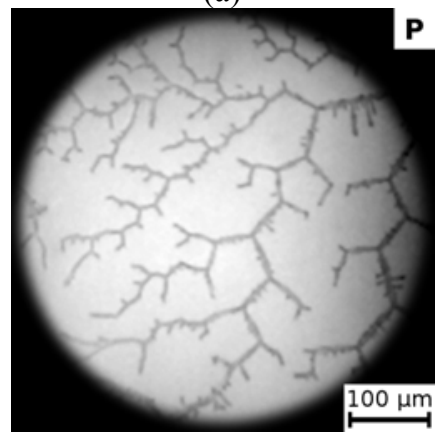

(d)

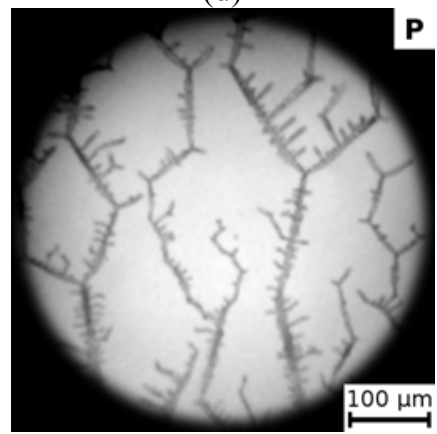

(g)

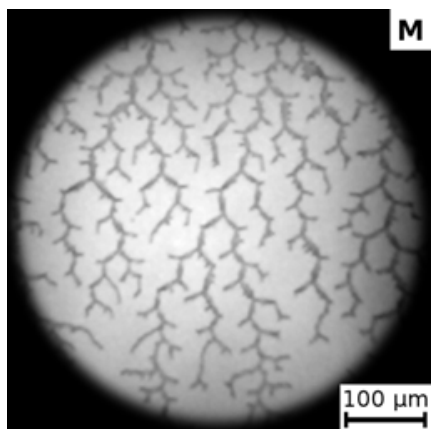

(b)

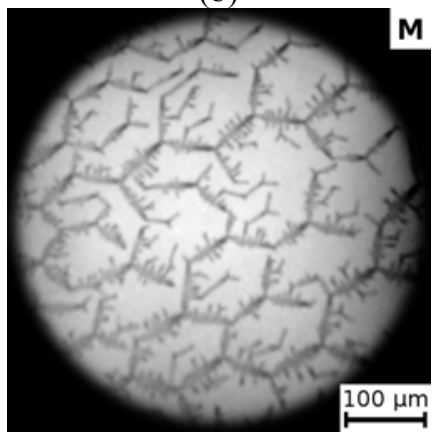

(e)

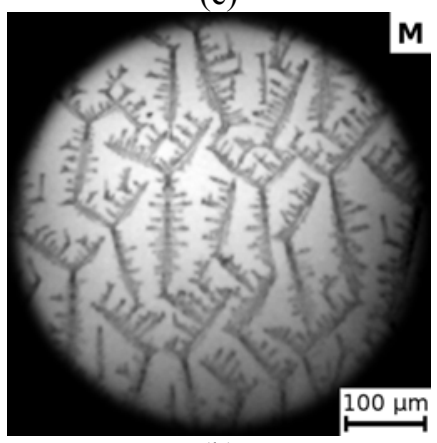

(h)

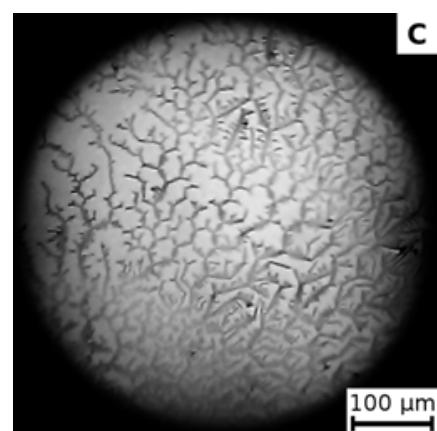

(c)

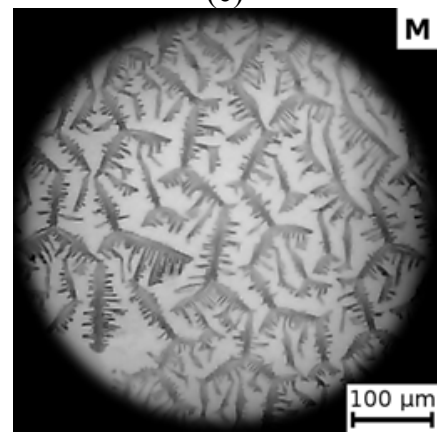

(f)

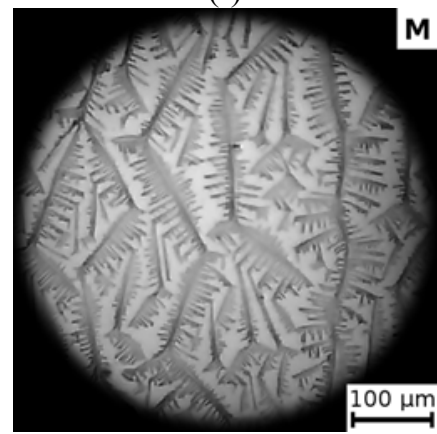

(i)

Fig. 1. Photos of zigzag patterns on the surface of BSA films with different segment lengths, pattern density and angles between segments: (a), (b), (c): low, medium and high density patterns for small segment lengths; (d), (e), (f): similarly for medium segment lengths; (g), (h), (i): similarly for long segment lengths. All films were obtained from control solutions; the letter in the upper right corner of each photo indicates whether the photo was taken in the center of the film $(\mathrm{C})$, on the periphery $(\mathrm{P})$, or between the center and the periphery $(\mathrm{M})$. 
They consist of connected linear segments of length $\mathrm{L}_{\mathrm{i}}$, each pair of which is at an angle $\alpha_{i, j}(i, j$ are neighboring segments) to each other. Another important characteristic is the density of patterns (i.e. how densely they cover the surface of the film). Fig. 1 shows photographs illustrating the variability of these parameters for films obtained from identical BSA solutions under identical conditions.

The films obtained in our experiments have an area of $20 \times 20 \mathrm{~mm}^{2}$. The photographs of the patterns (100 photographs for each film) together cover about $10 \%$ of the film area, which gives a sufficient sample for estimating the statistical distributions of zigzag characteristics.

Fig. 2 shows the characteristic histograms of the distributions of zigzag segment lengths and of angles between the segments. Via curve fitting, it was found that the typical distribution of segment lengths is closest to the lognormal distribution (which, presumably, corresponds to the model of multiplicative growth [25]), and the typical distribution of angles is closest to the logistic distribution.

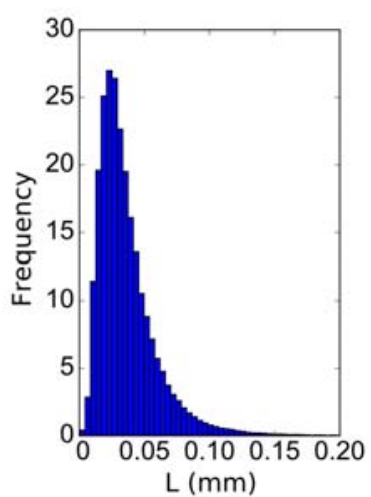

(a)

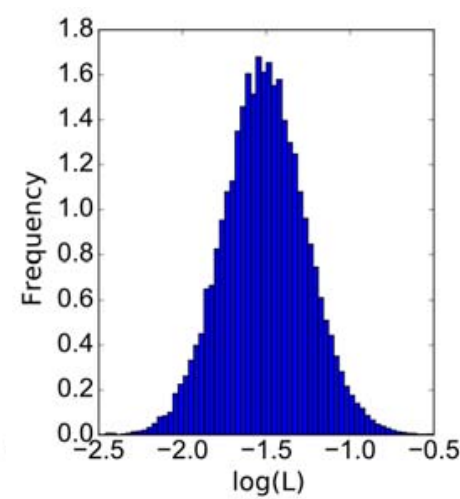

(b)

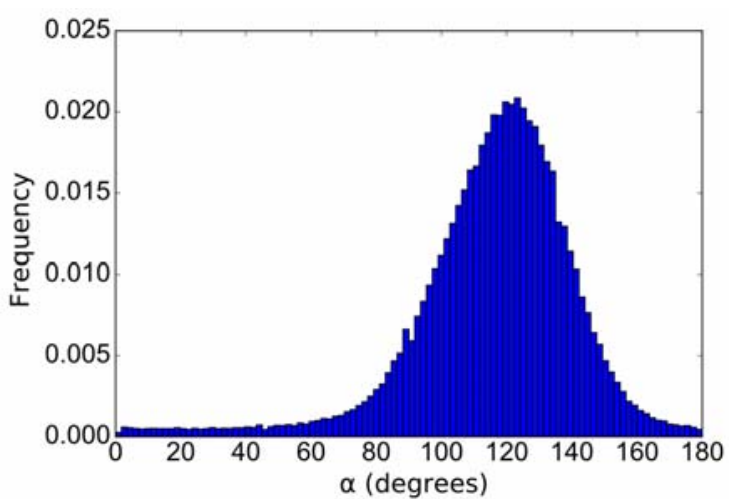

(c)

Fig. 2. Distributions of segment lengths in linear (a) and logarithmic (b) scales, and of angles between zigzag segments (c). The histograms were created from the aggregated data of all films analyzed in the paper.

Preliminary analysis has shown that the most informative in one or more series of experiments are the values of $\mathrm{L}_{\text {count }}$ (total number of zigzag segments), $\mathrm{L}_{\text {sum }}$ (total length of segments), $\mathrm{L}_{\text {mean }}$ (mean segment length), $\alpha_{\text {mean }}$ (mean angle between segments), as well as shape parameters of fitted functions of Burr ${ }^{\mathrm{XII}}[26]$

$$
\operatorname{Burr}^{12}(x, c, d)=c \cdot d \cdot x^{c-1} \cdot\left(1+x^{c}\right)^{-d-1},
$$

and Inverse Weibull [27]

$$
\operatorname{InvWeibull}(x, c)=c \cdot x^{-c-1} \cdot e^{-x^{-c}},
$$

where $x$ is the independent variable (segment length in our case), and $c, d$ are the shape parameters of the distributions.

In addition to these characteristics, the median, standard deviation, skewness and kurtosis of the distributions, as well as parameters of Log-Normal, Johnson $\mathrm{S}_{\mathrm{U}}$, Generalized Logistic and Exponentially modified Gaussian fitted functions were also considered. However, they did not prove to be informative at describing zigzag patterns, and so will be omitted.

The value of $\mathrm{L}_{\text {specific }}$ (the specific length of zigzags), which was used in our previous publications $[17-19,22,23]$, is proportional to $\mathrm{L}_{\text {sum: }}$ :

$$
L_{\text {specific }}=\frac{L_{\text {sum }}}{N_{\text {photos }} \cdot S_{\text {microscope }}},
$$

where $\mathrm{N}_{\text {photos }}$ is the number of photographs (100), and $\mathrm{S}_{\text {microscope }}$ is the area of the film visible under the microscope $\left(0.414 \mathrm{~mm}^{2}\right)$. As such, we will not mention it further.

$\mathrm{L}_{\text {sum }}, \mathrm{L}_{\text {count }}$ and $\mathrm{L}_{\text {mean }}$ relate to each other as 


$$
L_{\text {mean }}=L_{\text {sum }} / L_{\text {count }} \text {, }
$$

with $\mathrm{L}_{\text {sum }}$ and $\mathrm{L}_{\text {count }}$ in most cases having nearly identical dependence on the degree of exposure to a physical or chemical factor. Due to this, plots of $\mathrm{L}_{\text {sum }}$ will be presented only in a number of cases.

The behavior of the abovementioned characteristics in the corresponding series of experiments is analyzed below. The most illustrative dependencies are shown in the figures.

\section{Proportional change in component concentration}

In this experiment, the concentration of BSA $(1 \mathrm{mg} / \mathrm{ml})$ and $\mathrm{NaCl}(40 \mathrm{mM} / \mathrm{l})$ was doubled compared to the normally used concentration $(0.5 \mathrm{mg} / \mathrm{ml} \mathrm{BSA}, 20 \mathrm{mM} / \mathrm{l} \mathrm{NaCl})$. $\mathrm{L}_{\text {count }}$ (Fig. 3, a), $\mathrm{L}_{\text {sum }}$ and $\alpha_{\text {mean }}$ (Fig. 3, b) remained in the range of the values for the $100 \%$ concentration. $\mathrm{L}_{\text {mean }}$ (Fig. 3, c) at a doubled concentration does not go beyond the limits of the values observed at the usual concentration, but on average is much higher. For the $200 \%$ concentration, the Burr ${ }^{\mathrm{XII}} \mathrm{C}$ parameter (Fig. 3, d) is smaller than for the $100 \%$ concentration (the decrease of Burr ${ }^{\mathrm{XII}} \mathrm{C}$ corresponds to the distribution "stretching" and shifting towards larger values).

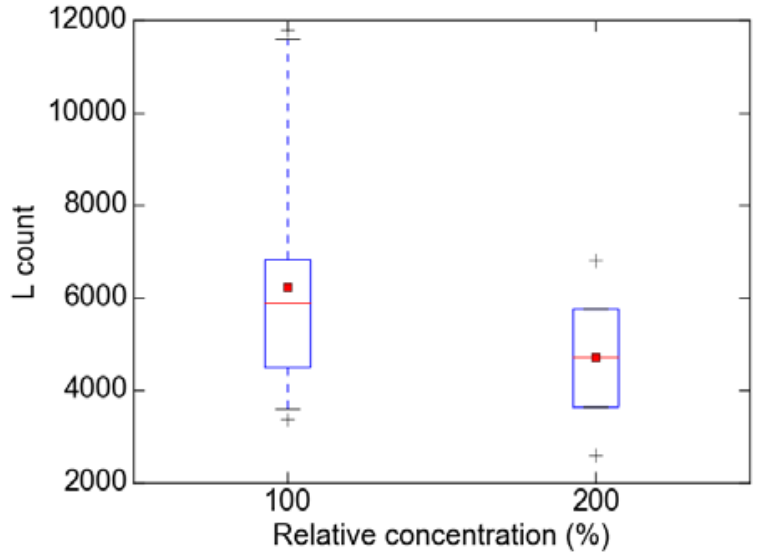

(a)

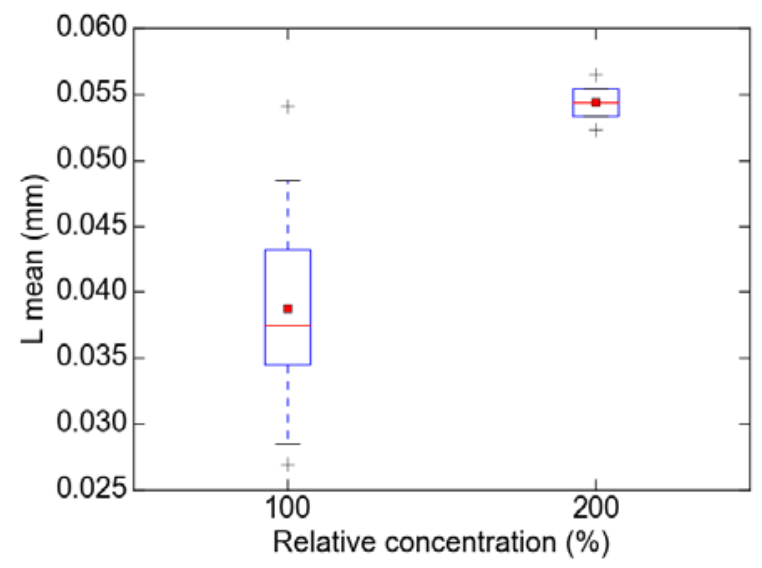

(c)

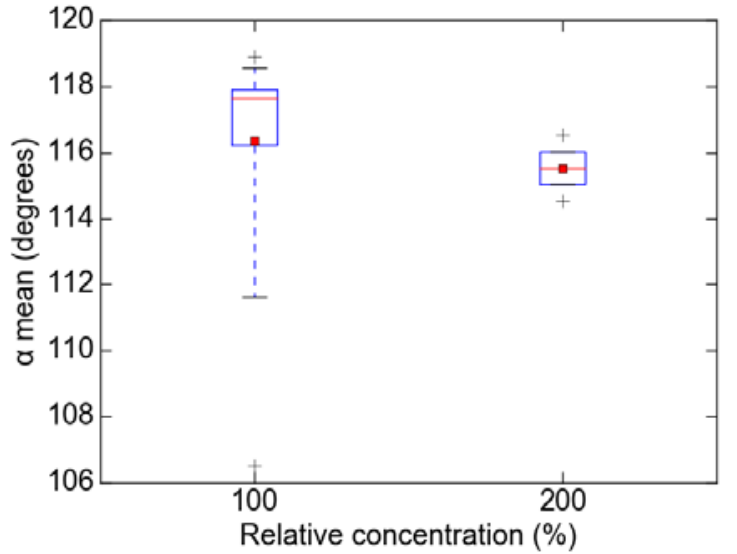

(b)

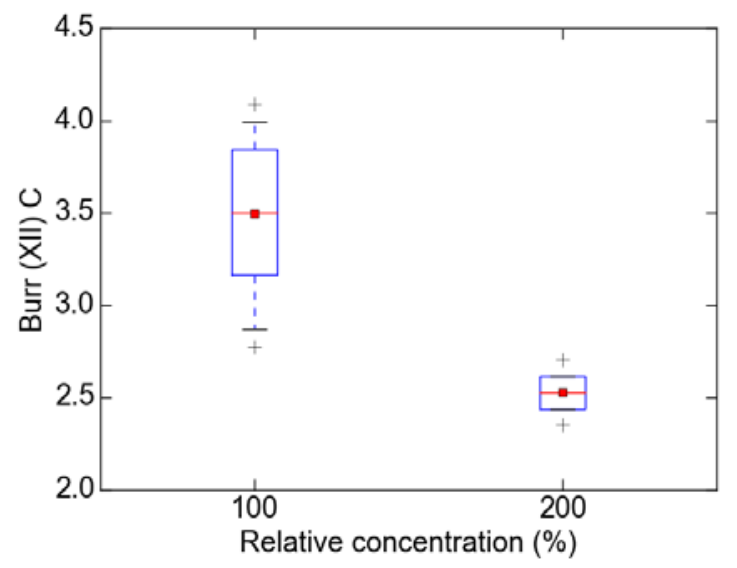

(d)

Fig. 3. Pattern characteristics at standard and doubled concentration of components of the biopolymer solution: (a) number of zigzag segments; (b) average angle between zigzag segments; (c) average length of zigzag segments; (d) shape parameter $\mathrm{C}$ of the Burr ${ }^{\mathrm{XII}}$ distribution. Box plot notation: boxes correspond to 25 and 75 percentiles, dotted lines correspond to 5 and 95 percentiles, crosses correspond to minimum and maximum values, horizontal lines correspond to medians, and squares correspond to mean values. Control: 18 films; $200 \%$ concentration: 2 films. 
With an increase in the concentration of salt and protein, the average length of segments and the spread of segment lengths increase. Based on the model descibed in [20], it can be assumed that a higher concentration of components allows the crystal to grow for a longer time in one direction.

\section{Substituting $\mathrm{Cl}^{-}$with $\mathrm{Br}^{-}$and $\mathrm{F}^{-}$}

In this experiment [18], it was investigated whether zigzags can form when chlorine ions are partially or completely replaced by other halides (bromine or fluorine). The concentration of salts varied from 20 to $0 \mathrm{mM} / 1$ for $\mathrm{NaCl}$ and from 0 to $20 \mathrm{mM} / 1$ for $\mathrm{NaBr}$ and $\mathrm{NaF}$, respectively.

Replacing sodium chloride with sodium bromide resulted in the following (Fig. 4, a, c, e): up to $4 \mathrm{mM} / 1 \mathrm{NaBr}, \mathrm{L}_{\text {count }}$ and $\mathrm{L}_{\text {sum }}$ stay in the range of control values; at $8 \mathrm{mM} / 1 \mathrm{NaBr}$, they noticeably decrease; at $16 \mathrm{mM} / 1 \mathrm{NaBr}$ and more, zigzags are not formed. $\alpha_{\text {mean }}, \mathrm{L}_{\text {mean }}$ and the parameters of fitted functions do not go beyond the range of values for control.

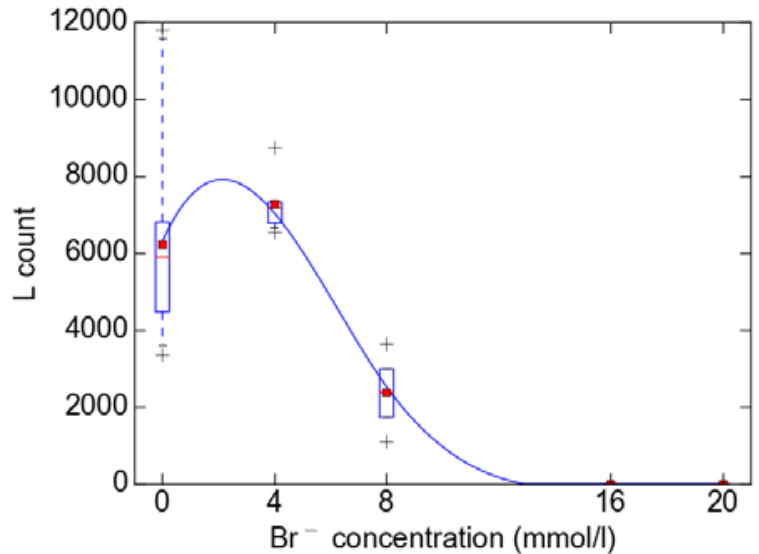

(a)

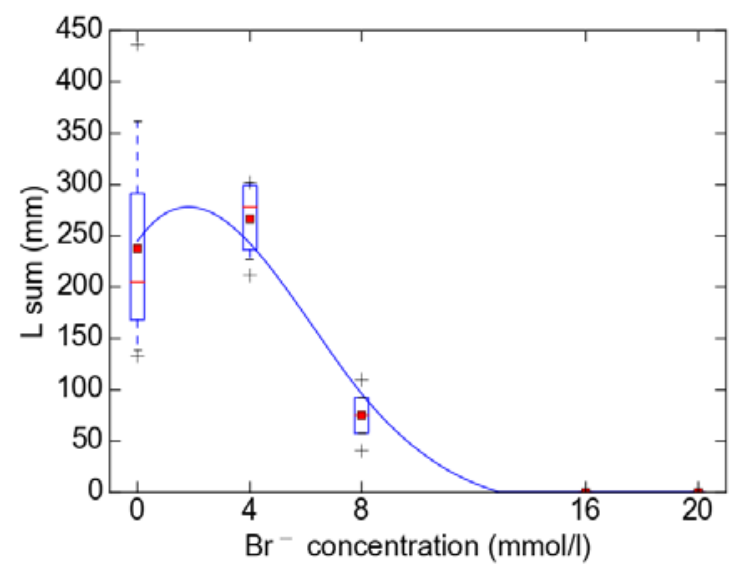

(c)

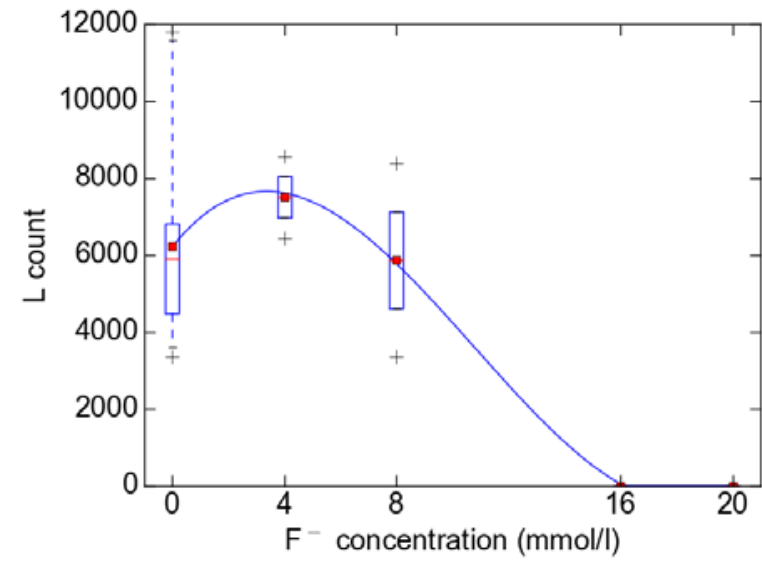

(b)

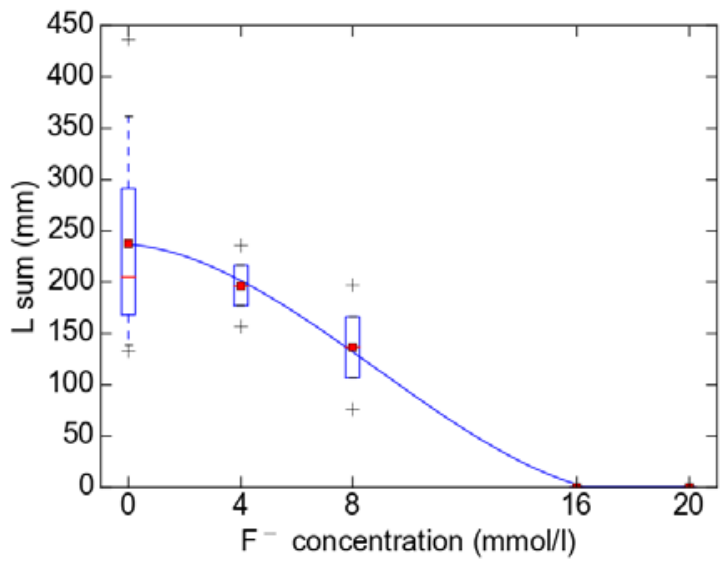

(d)

Fig. 4. Pattern characteristics when $\mathrm{NaCl}$ is replaced by $\mathrm{NaBr}(\mathrm{a}, \mathrm{c})$ and $\mathrm{NaF}(\mathrm{b}, \mathrm{d})$ : (a), (b) number of zigzag segments; (c), (d) total length of zigzag segments. Box plot notation: boxes correspond to 25 and 75 percentiles, dotted lines correspond to 5 and 95 percentiles, crosses correspond to minimum and maximum values, horizontal lines correspond to medians, and squares correspond to mean values. Control: 18 films; 4 $\mathrm{mM} / 1 \mathrm{Br}^{-}: 5$ films; $8 \mathrm{mM} / 1 \mathrm{Br}^{-}: 2$ films; $16 \mathrm{mM} / 1 \mathrm{Br}^{-}: 1$ film; $20 \mathrm{mM} / 1 \mathrm{Br}^{-}: 2$ films; $4 \mathrm{mM} / 1 \mathrm{~F}^{-}: 2$ films; $8 \mathrm{mM} / 1$ $\mathrm{F}^{-}: 2$ films; $16 \mathrm{mM} / 1 \mathrm{~F}^{-}: 1$ film; $20 \mathrm{mM} / \mathrm{l} \mathrm{F}^{-}: 2$ films. 


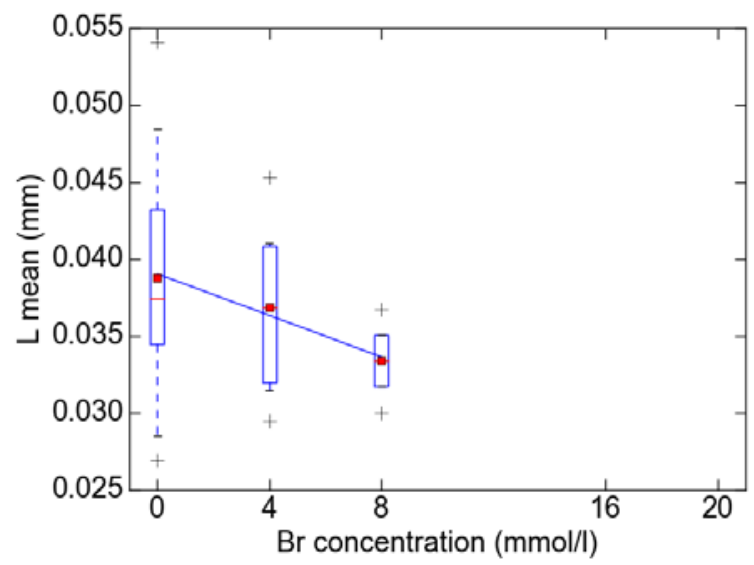

(e)

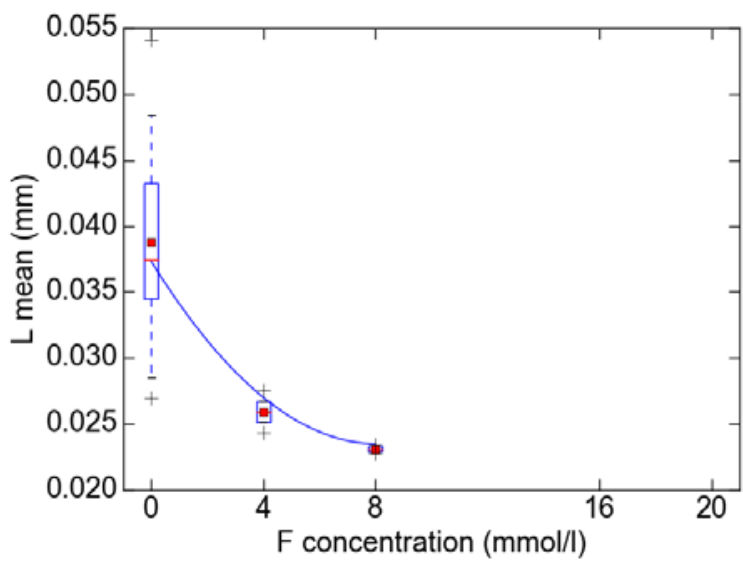

(f)

Fig. 4 (continuation). Pattern characteristics when $\mathrm{NaCl}$ is replaced by $\mathrm{NaBr}$ (e) and $\mathrm{NaF}$ (f): (e), (f) average length of zigzag segments. Box plot notation: boxes correspond to 25 and 75 percentiles, dotted lines correspond to 5 and 95 percentiles, crosses correspond to minimum and maximum values, horizontal lines correspond to medians, and squares correspond to mean values. Control: 18 films; $4 \mathrm{mM} / 1 \mathrm{Br}^{-}: 5$ films; $8 \mathrm{mM} / 1$ $\mathrm{Br}^{-}: 2$ films; $4 \mathrm{mM} / 1 \mathrm{~F}^{-}: 2$ films; $8 \mathrm{mM} / \mathrm{F}^{-}: 2$ films.

Replacing sodium chloride with sodium fluoride resulted in the following (Fig. 4, b, d, f): up to $8 \mathrm{mM} / 1 \mathrm{NaF}, \mathrm{L}_{\text {count }}$ values are in the range of control values; up to $8 \mathrm{mM} / 1 \mathrm{NaF} \mathrm{L}_{\text {sum }}$ tends to decrease, but the ranges of its values are at least partly overlapping. At $16 \mathrm{mM} / 1 \mathrm{NaF}$ and more, zigzags are not formed. $\alpha_{\text {mean }}$ tends to decrease, but does not go beyond the extreme values of control. $\mathrm{L}_{\text {mean }}$ decreases with increasing $\mathrm{NaF}$ concentration, and the ranges of its values at 0,4 and $8 \mathrm{mM} / 1 \mathrm{NaF}$ practically do not overlap.

At $4 \mathrm{mM} / 1 \mathrm{Cl}^{-}$(20\% of the usual concentration) and below, zigzags do not form, which indicates a high specificity of the zigzag aggregation mode to the physical parameters of the anions (size, surface charge, etc.). $\mathrm{Br}^{-}$and $\mathrm{F}^{-}$also influence the conformation of BSA and have a lower degree of hydration than $\mathrm{Cl}^{-}$(which affects electrostatic interactions) [18]. $\mathrm{Br}^{-}$ and $\mathrm{F}^{-}$themselves do not create conditions for the formation of zigzag patterns, but their presence has different effects: at $8 \mathrm{mM} / 1 \mathrm{Br}^{-}$, the number of zigzag segments markedly decreases, while $\mathrm{F}^{-}$noticeably reduces the average length of zigzag segments.

\section{Heat treatment of BSA solutions}

In this experiment [18], solutions of BSA with $\mathrm{NaCl}$ were heated to 45,70 and $95{ }^{\circ} \mathrm{C}$ to find out what contribution the structural state of the protein makes to the formation of zigzag patterns. The values of $\mathrm{L}_{\text {count }}$ (Fig. 5, a) and $\mathrm{L}_{\text {sum }}$ for 20 and $45{ }^{\circ} \mathrm{C}$ are in the same range, at $70{ }^{\circ} \mathrm{C}$ they decrease considerably, and at $95^{\circ} \mathrm{C}$ zigzags are not formed. The values of $\alpha_{\text {mean }}$ for 20 and $45^{\circ} \mathrm{C}$ are in the same range, and at $70{ }^{\circ} \mathrm{C}$ they increase (Fig. 5, b). $\mathrm{L}_{\text {mean }}$ practically does not change at different temperatures (Fig. 5, c). At $70{ }^{\circ} \mathrm{C}$, the Burr ${ }^{\mathrm{XII}} \mathrm{C}$ parameter (Fig. 5, d) decreases compared to 20 and $45^{\circ} \mathrm{C}$.

At $60{ }^{\circ} \mathrm{C}$, BSA begins to unfold and form primary aggregates, at $70{ }^{\circ} \mathrm{C}$ it forms primary and secondary aggregates, and at $80{ }^{\circ} \mathrm{C}$ it forms aggregates of large size [28]. Since at $70{ }^{\circ} \mathrm{C}$ the amount of zigzags is noticeably reduced, and at $95{ }^{\circ} \mathrm{C}$ they are completely absent, it can be unequivocally asserted that protein aggregation disrupts the conditions for the formation of zigzag patterns. Also, at $70{ }^{\circ} \mathrm{C}$, compared to the control, the mean angle between the $\alpha_{\text {mean }}$ segments slightly increases and scatter of segment lengths increases (which is reflected in the reduced Burr ${ }^{\mathrm{XII}} \mathrm{C}$ ), but the average length $\mathrm{L}_{\text {mean }}$ remains almost the same. These observations suggest that the state of the biopolymer mainly affects the number of zigzag segments, and the concentration of chlorine mainly affects the length of the segments. 
Characterization of zigzag patterns on the surface of bovine serum albumin films

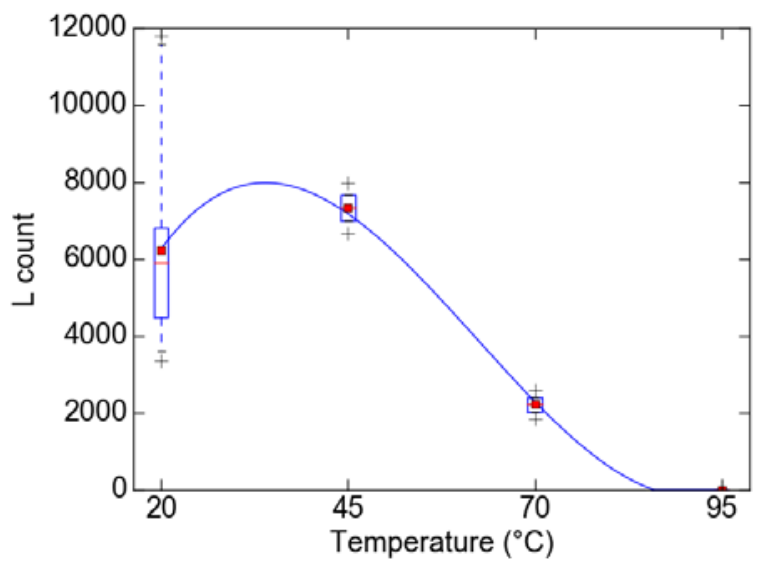

(a)

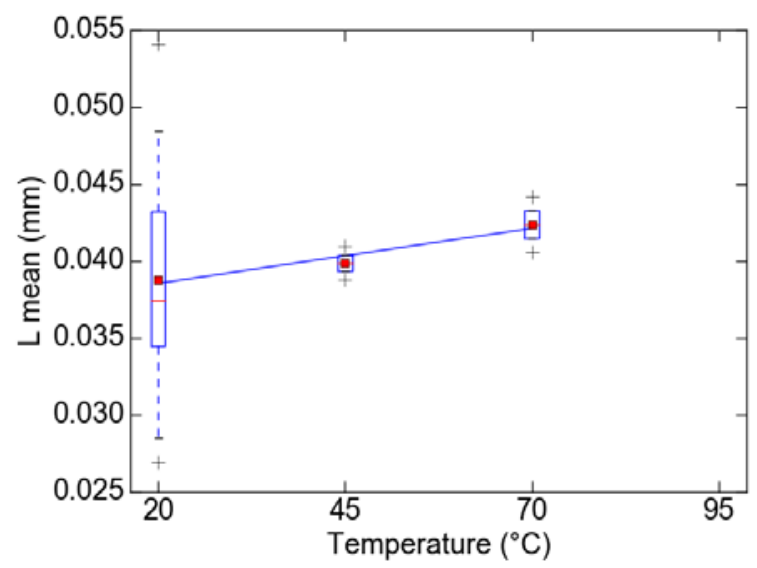

(c)

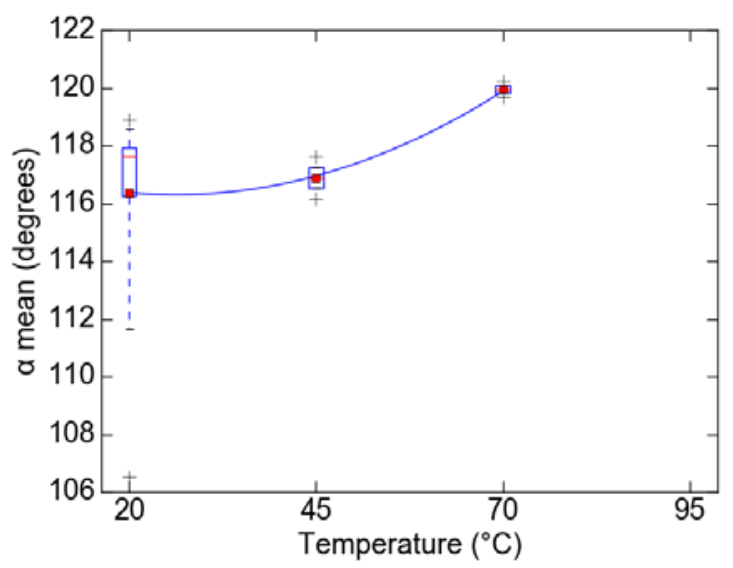

(b)

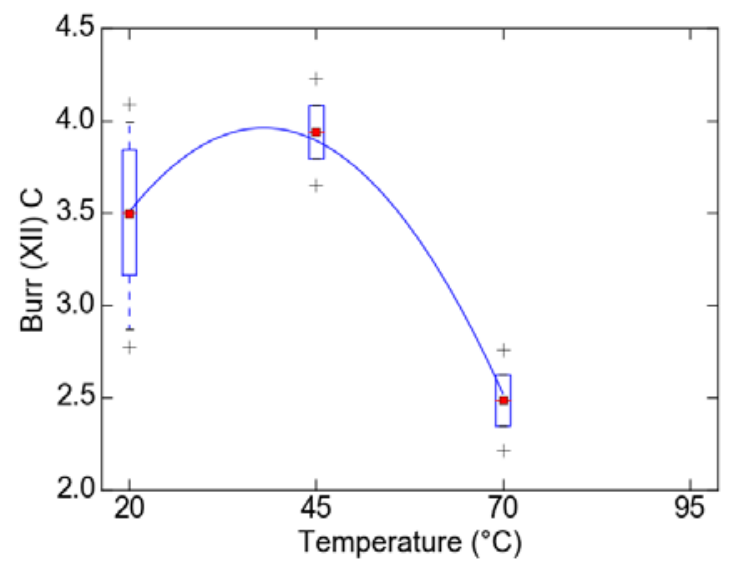

(d)

Fig. 5. Patterns characteristics after the temperature treatment of the biopolymer solution: (a) number of zigzag segments; (b) average angle between zigzag segments; (c) average length of zigzag segments; (d) shape parameter $\mathrm{C}$ of the Burr ${ }^{\mathrm{XII}}$ distribution. Box plot notation: boxes correspond to 25 and 75 percentiles, dotted lines correspond to 5 and 95 percentiles, crosses correspond to minimum and maximum values, horizontal lines correspond to medians, and squares correspond to mean values. Control: 18 films; $45^{\circ} \mathrm{C}: 2$ films; $70{ }^{\circ} \mathrm{C}: 2$ films; $90{ }^{\circ} \mathrm{C}: 2$ films.

\section{Gamma irradiation of BSA solutions by ${ }^{60} \mathrm{Co}$}

In this experiment [22], solutions of $\mathrm{BSA}$ with $\mathrm{NaCl}$ were subjected to gamma irradiation in $0.16-12000$ Gy dose range. $\mathrm{L}_{\text {count }}$ (Fig. 6, a) and $\mathrm{L}_{\text {sum }}$ for the intermediate doses have both values close to zero, and values that fall in the confidence interval of the control; from a statistical point of view, doses of $1-2000$ Gy are practically indistinguishable. Only at 12000 Gy zigzags completely cease to form. $\alpha_{\text {mean }}$ and $L_{\text {mean }}$ (Fig. 6, b, c) vary in approximately the same range at all doses. Parameters of the fitted functions, for example, Burr ${ }^{\mathrm{XII}} \mathrm{C}$ (Fig. 6, d), also have too large variations to distinguish intermediate doses.

Gamma irradiation leads to the formation of free radicals in solution, which cause protein fragmentation. According to the data of SDS-PAGE (dodecyl sulfate polyacrylamide gel electrophoresis), polypeptide chain breaks down at doses up to $1 \mathrm{kGy}$, and at $5 \mathrm{kGy}$ or higher fragments of the destroyed protein begin to form large molecular weight aggregates [29]. Specifically, doses up to $0.2 \mathrm{kGy}$ damage $10-20 \%$ of BSA [30]; at $1 \mathrm{kGy}, 50-60 \%$ of BSA is damaged [30], and even at $2.5 \mathrm{kGy}$ some amount of undamaged BSA still remains [31]. In our case, the ionizing radiation changes the number of zigzag segments, but the average length $\mathrm{L}_{\text {mean }}$, angles $\left(\alpha_{\text {mean }}\right)$ and other distribution parameters are practically independent of the dose. At $12 \mathrm{kGy}$ (aggregation of protein fragments), zigzags never form, but in the dose 
range of $1-2000 \mathrm{~Gy}$ (protein destruction), the amount of zigzags on a given film can turn out to be anything from near-zero to the amount typical for the control. This suggests that, unlike the formation of aggregates, biopolymer fragmentation does not have unambiguous effect on the formation of zigzag patterns.

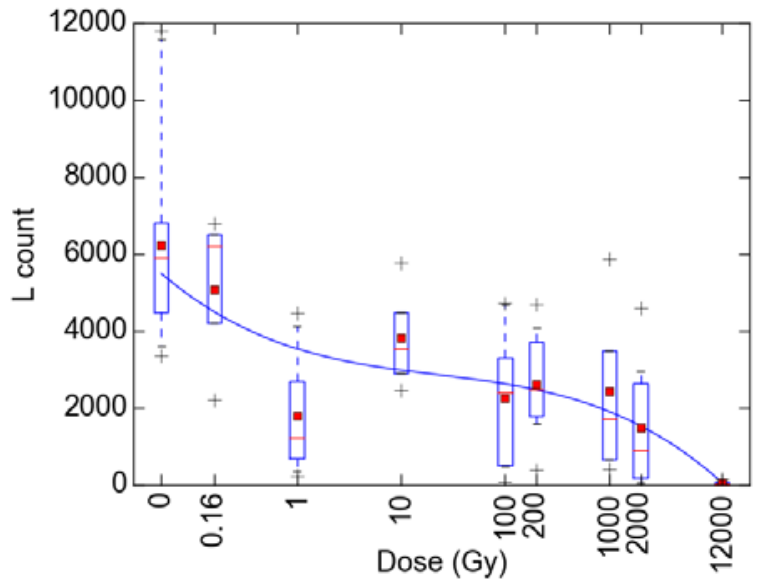

(a)

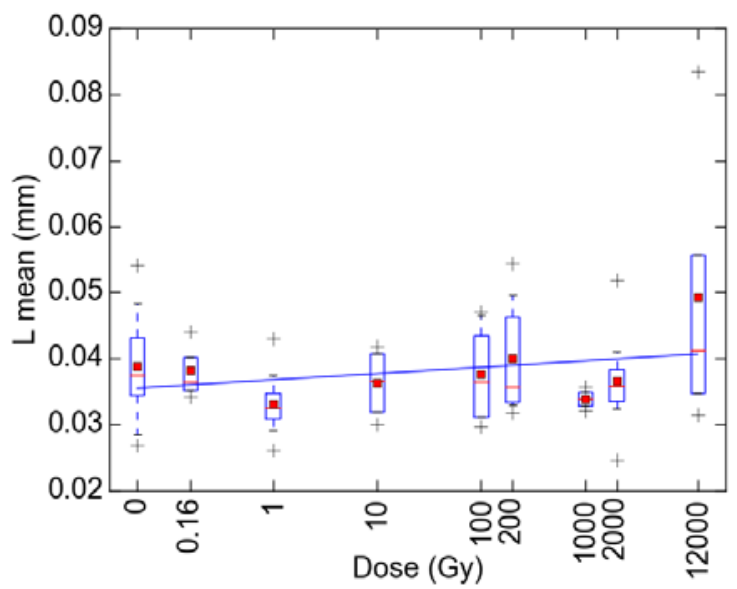

(c)

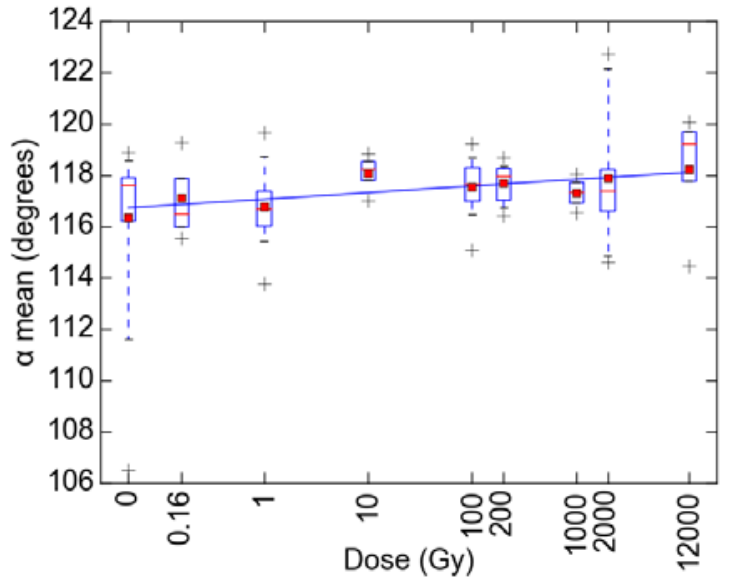

(b)

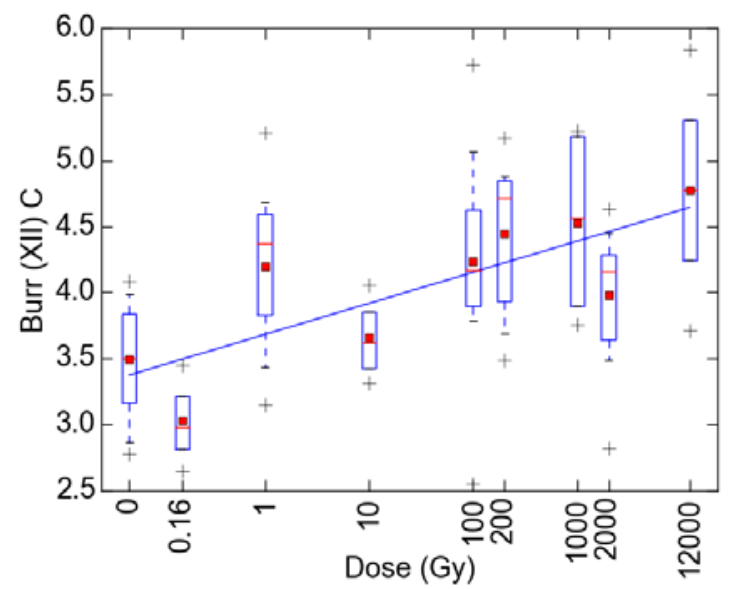

(d)

Fig. 6. Pattern characteristics after gamma irradiation of the biopolymer solution: (a) number of zigzag segments; (b) average angle between zigzag segments; (c) average length of zigzag segments; (d) shape parameter $\mathrm{C}$ of the Burr ${ }^{\mathrm{XII}}$ distribution. Box plot notation: boxes correspond to 25 and 75 percentiles, dotted lines correspond to 5 and 95 percentiles, crosses correspond to minimum and maximum values, horizontal lines correspond to medians, and squares correspond to mean values. Control: 18 films; 0.16 Gy: 3 films; 1 Gy: 12 films; 10 Gy: 4 films; 100 Gy: 8 films; 200 Gy: 6 films; 1 kGy: 4 films; 2 kGy: 10 films; 12 kGy: 4 films.

\section{Addition of $\mathrm{FeCl}_{3}$ to $\mathrm{BSA}$ solutions}

In this experiment [19], $\mathrm{FeCl}_{3}$ salt in the concentration range of $0.05-0.4 \mathrm{mM} / 1$ was added to the solutions of BSA with $\mathrm{NaCl}$. $\mathrm{L}_{\text {sum }}$ and $\mathrm{L}_{\text {count }}$ (Fig. 7, a, b) up to $0.15 \mathrm{mM} / \mathrm{l}$ of $\mathrm{FeCl}_{3}$ stay in the range of control values, but starting from $0.2 \mathrm{mM} / 1$ they noticeably decrease. When $\mathrm{FeCl}_{3}$ concentration reaches $0.3 \mathrm{mM} / 1$, the probability of zigzag formation decreases even more, and starting from $0.4 \mathrm{mM} / 1$ of $\mathrm{FeCl}_{3}$ zigzags stop forming completely. For $\alpha_{\text {mean }}$ and $\mathrm{L}_{\text {mean }}$ (Fig. 7, c, d), there is no evident dependence on the concentration of $\mathrm{FeCl}_{3}$. The parameters of the fitted functions also behave in a manner similar to either $\mathrm{L}_{\text {count }}$ or $\mathrm{L}_{\text {mean }}$.

If $\mathrm{FeCl}_{3}$ is added to the BSA solution, the number of zigzag segments ( $\mathrm{L}_{\text {count }}$ ) changes, but no dependence of distribution parameters on the iron concentration is observed. $\mathrm{L}_{\text {count }}$ has several very distinct areas: up to $0.15 \mathrm{mM} / 1 \mathrm{FeCl}_{3}, \mathrm{~L}_{\text {count }}$ is in the range of control values and even has an upward tendency; between 0.2 and $0.25 \mathrm{mM} / 1 \mathrm{FeCl}_{3}$, the amount of zigzags is 
markedly reduced and varies in approximately the same range; at $0.3 \mathrm{mM} / 1, \mathrm{~L}_{\text {count }}$ decreases again, and at $0.4 \mathrm{mM} / 1 \mathrm{FeCl}_{3}$ zigzags cease to form. At the moment, we find it difficult to hypothesize what could be the cause of such a threshold effect. According to the data of [32], even at a 50:1 concentration ratio, only 0.79 mole of $\mathrm{Fe}^{3+}$ binds to 1 mole of BSA, and this does not cause obvious changes in the secondary structure of BSA. It might be that, upon reaching a certain concentration of $\mathrm{FeCl}_{3}$, another morphology with a higher growth rate becomes possible, which, according to the hypothesis of [33], will lead to the suppression of other types of patterns.

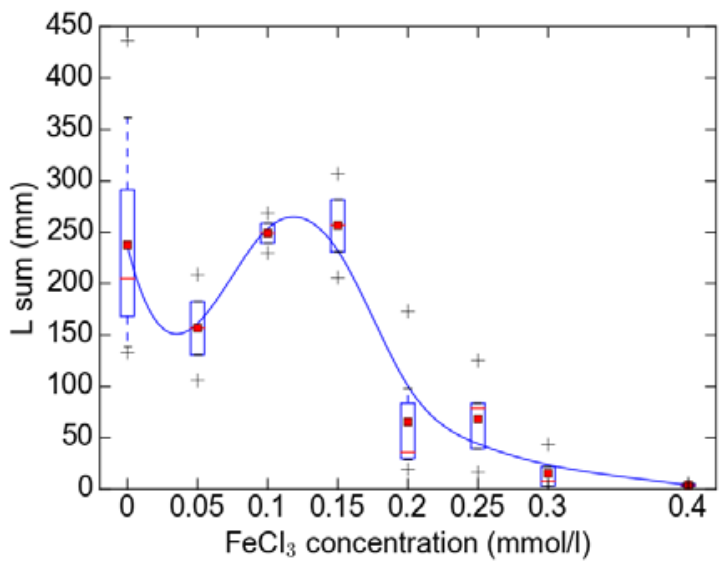

(a)

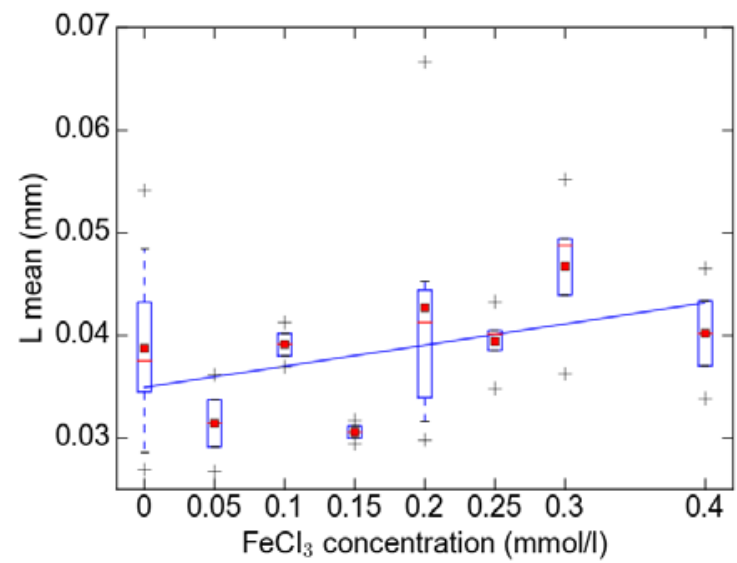

(c)

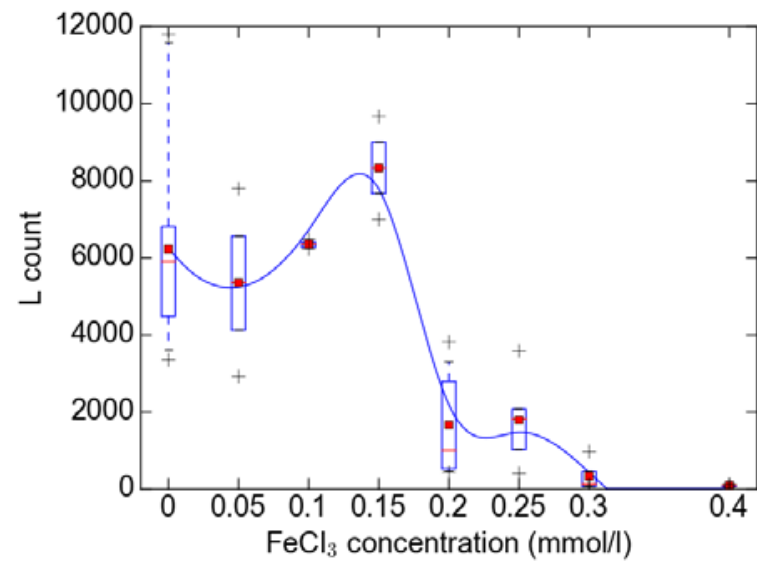

(b)

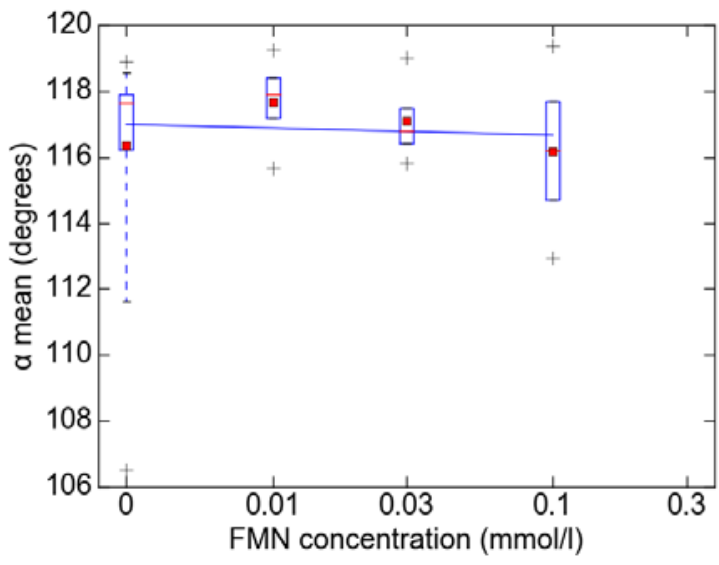

(d)

Fig. 7. Pattern characteristics when $\mathrm{FeCl}_{3}$ is added to the biopolymer solution: (a) total length of zigzag segments; (b) number of zigzag segments; (c) average length of zigzag segments; (d) average angle between zigzag segments. Box plot notation: boxes correspond to 25 and 75 percentiles, dotted lines correspond to 5 and 95 percentiles, crosses correspond to minimum and maximum values, horizontal lines correspond to medians, and squares correspond to mean values. Control: 18 films; $0.05 \mathrm{mM} / 1 \mathrm{FeCl}_{3}: 2$ films; $0.1 \mathrm{mM} / 1 \mathrm{FeCl} \mathrm{l}_{3}: 2$ films; $0.15 \mathrm{mM} / 1 \mathrm{FeCl}_{3}: 2$ films; $0.2 \mathrm{mM} / 1 \mathrm{FeCl}_{3}: 7$ films; $0.25 \mathrm{mM} / 1 \mathrm{FeCl}_{3}: 5$ films; $0.3 \mathrm{mM} / 1 \mathrm{FeCl}$ : 5 films; $0.4 \mathrm{mM} / 1$ $\mathrm{FeCl}_{3}: 2$ films.

\section{Addition of flavin mononucleotide to BSA solutions}

In this experiment [23], flavin mononucleotide (FMN) in the concentration range of $0.01-0.3 \mathrm{mM} / 1$ was added to the solutions of BSA with $\mathrm{NaCl}$. $\mathrm{L}_{\text {count }}\left(\right.$ Fig. 8, a) and $\mathrm{L}_{\text {sum }}$ at $0.01 \mathrm{mM} / 1$ still fall within the range of control values, but $0.03 \mathrm{mM} / 1$ of FMN already significantly inhibits the formation of zigzag patterns. At $0.3 \mathrm{mM} / 1$, zigzags completely cease to form. $\alpha_{\text {mean }}$ and $\mathrm{L}_{\text {mean }}$ (Fig. $8, \mathrm{~d}, \mathrm{c}$ ) remain approximately in the range of control values. The parameter Inverse Weibull C (Fig. 8, b) increases with the increase of FMN concentration (the 
growth of Inverse Weibull C corresponds to the distribution "shrinkage" and shifting towards larger values).

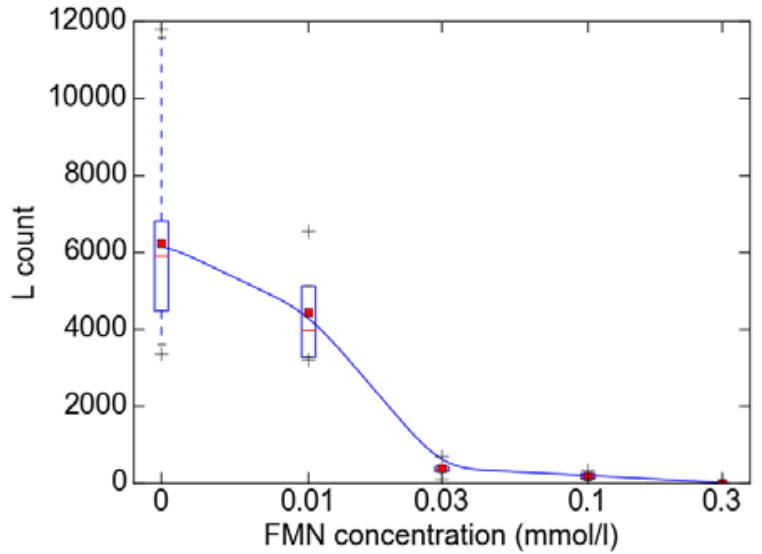

(a)

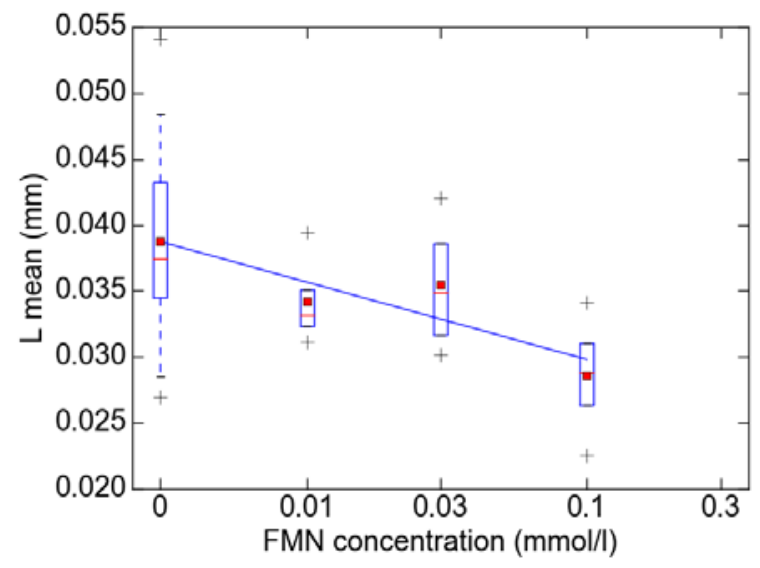

(c)

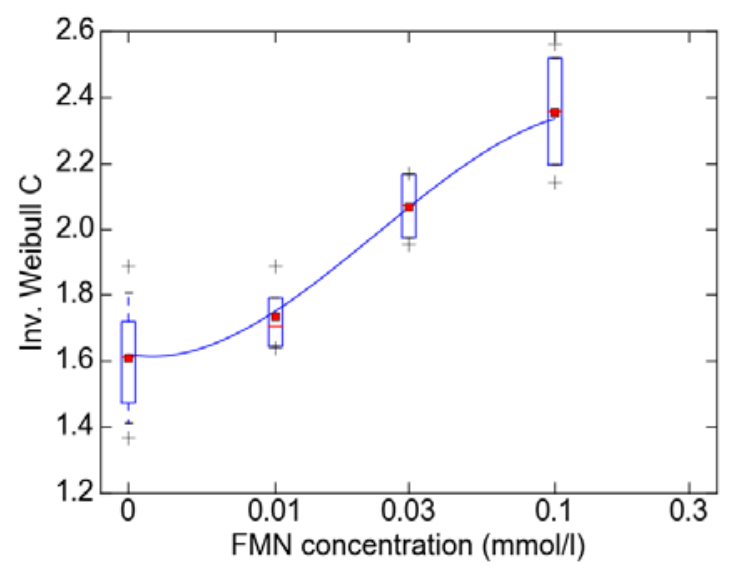

(b)

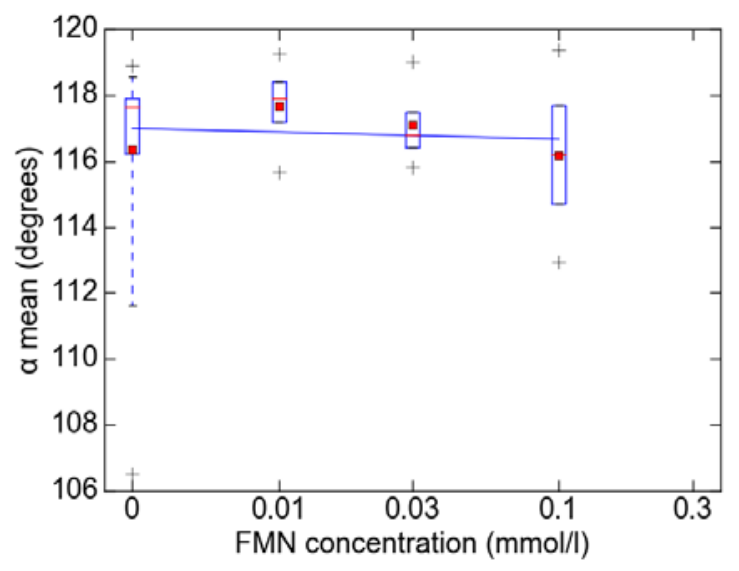

(d)

Fig. 8. Pattern characteristics when flavin mononucleotide is added to the biopolymer solution: (a) number of zigzag segments; (b) shape parameter C of the Inverse Weibull distribution; (c) average length of zigzag segments; (d) average angle between zigzag segments. Box plot notation: boxes correspond to 25 and 75 percentiles, dotted lines correspond to 5 and 95 percentiles, crosses correspond to minimum and maximum values, horizontal lines correspond to medians, and squares correspond to mean values. Control: 18 films; $0.01 \mathrm{mM} / 1$ FMN: 4 films; $0.03 \mathrm{mM} / 1$ FMN: 4 films; $0.1 \mathrm{mM} / 1$ FMN: 4 films; $0.3 \mathrm{mM} / 1$ FMN: 4 films.

Addition of $0.01 \mathrm{mM} / 1 \mathrm{FMN}$ does not shift the characteristics of zigzag patterns beyond the range of control values. However, starting from $0.03 \mathrm{mM} / 1$, the number of segments and the spread of segment lengths are sharply reduced. Average segment lengths $\left(\mathrm{L}_{\text {mean }}\right)$ and angles between segments $\left(\alpha_{\text {mean }}\right)$ practically do not change. According to the studies [34-36], HSA and BSA form complexes with riboflavin (RF), flavin adenine dinucleotide (FAD) and FMN at a ratio of 1:1 and with high binding constants; in [36] it was also shown that, in the presence of RF, BSA conformation changes and its hydration increases. This agrees with the results obtained by spectroscopy and microwave dielectrometry for solutions of FMN with BSA [23]. In our case, at $0.01 \mathrm{mM} / 1 \mathrm{FMN}$, the number of FMN moleculer is 1.3 times the number of BSA molecules, and at $0.03 \mathrm{mM} / 1$ it is 4 times the number of BSA molecules. It can be assumed that the conditions for the formation of zigzag patterns are violated by the presence of free FMN, but not by the binding of FMN to BSA. 
Characterization of zigzag patterns on the surface of bovine serum albumin films

Table 1 summarizes the effect of the factors studied in this paper on the values of $\mathrm{L}_{\text {count }}$ and $\mathrm{L}_{\text {mean. }}$. The behavior of these characteristics is compared to the structural state of the protein according to the published data.

Table 1

Effect of certain physical and chemical factors on the $\mathrm{L}_{\text {count }}$ and $\mathrm{L}_{\text {mean }}$ characteristics of films obtained from saline solutions of BSA in various experiments

\begin{tabular}{|c|c|c|}
\hline Experiment & Effect on $L_{\text {count }}$ and $L_{\text {mean }}$ & Structural state of the protein \\
\hline $\begin{array}{l}\text { Doubling the } \\
\text { concentration of } \\
\mathrm{BSA} \text { and } \mathrm{NaCl}\end{array}$ & $\begin{array}{l}\mathrm{L}_{\text {mean }} \text { increases with increasing } \\
\text { concentration }\end{array}$ & Not violated \\
\hline $\begin{array}{l}\text { Replacing } \mathrm{Cl}^{-} \\
\text {with } \mathrm{Br}^{-} \text {or } \mathrm{F}^{-}\end{array}$ & $\begin{array}{l}\text { Starting at } 8 \mathrm{MM} / л \mathrm{Br}^{-}, \mathrm{L}_{\text {count }} \text { decreases; } \\
\text { starting at } 4 \mathrm{MM} / л \mathrm{~F}^{-}, \mathrm{L}_{\text {mean }} \text { decreases }\end{array}$ & Not violated [37] \\
\hline Heat treatment & $\begin{array}{l}\mathrm{L}_{\text {count }} \text { decreases at } 70{ }^{\circ} \mathrm{C} \text { (formation of } \\
\text { aggregates) and becomes } 0 \text { at } 95^{\circ} \mathrm{C} \\
\text { (large aggregates) }\end{array}$ & $\begin{array}{l}\text { Denaturation and aggregation } \\
\text { of the protein [28] }\end{array}$ \\
\hline $\begin{array}{l}\text { Irradiation by } \\
{ }^{60} \mathrm{Co}\end{array}$ & $\begin{array}{l}\text { In the } 1-2000 \text { Gy range (destruction } \\
\text { of the protein) } \mathrm{L}_{\text {count }} \text { varies from almost } \\
\text { zero to the typical values for control; at } \\
12 \mathrm{kGy} \text { (aggregation) } \mathrm{L}_{\text {count }} \text { is equal to } 0\end{array}$ & $\begin{array}{l}\text { Up to } 1 \mathrm{kGy} \text { : protein } \\
\text { fragmentation [29]; starting } \\
\text { from } 5 \mathrm{kGy} \text { : aggregation of } \\
\text { fragments [29]; at } 2.5 \mathrm{kGy} \\
\text { some amount of undamaged } \\
\text { BSA still remains [31] }\end{array}$ \\
\hline $\begin{array}{l}\text { Addition of } \\
\mathrm{FeCl}_{3}\end{array}$ & $\begin{array}{l}\text { Up to } 0,15 \mathrm{mM} / 1 \mathrm{FeCl}_{3}, \mathrm{~L}_{\text {count }} \text { stays in } \\
\text { the range of control values, at } 0,2 \mathrm{mM} / 1 \\
\text { and } 0,3 \mathrm{mM} / 1 \text { it decreases in discrete } \\
\text { manner, and becomes } 0 \text { at } 0,4 \mathrm{mM} / 1\end{array}$ & $\begin{array}{l}\mathrm{Fe}^{3+} \text { does causes no obvious } \\
\text { changes in the secondary } \\
\text { structure of BSA [32] }\end{array}$ \\
\hline $\begin{array}{l}\text { Addition of } \\
\text { flavin } \\
\text { mononucleotide }\end{array}$ & $\begin{array}{l}\mathrm{L}_{\text {count }} \text { is significantly reduced in the } \\
\text { presence of an excess amount of FMN } \\
\text { not bound to the protein }\end{array}$ & $\begin{array}{l}\text { Flavin derivatives lead to a } \\
\text { change in the conformation and } \\
\text { an increase in the hydration of } \\
\text { BSA [36] }\end{array}$ \\
\hline
\end{tabular}

An additional observation, which is valid for all experiments, is that all the considered characteristics have a significant spread. It can be caused both by insufficient accuracy of the control of experimental conditions (the degree of purity of the cuvettes, the homogeneity of the solution, the inclination of the cuvette during drying), and by the chaotic character of the process of texture formation. The authors of $[14,15]$ consider the latter to be the case, as they also report low reproducibility and high variability of the results of the method of biocrystallization. According to their analysis, the crystallization stage is the primary source of the variability of results.

\section{CONCLUSIONS}

A number of characteristics of zigzag patterns, which form on films of dried BSA solutions, were analyzed in this paper. It was determined that the most informative among the characteristics considered are the number of zigzag segments $\mathrm{L}_{\text {count }}$ and their average length $\mathrm{L}_{\text {mean }}$, and the least informative is the average angle between segments. Other parameters either correlate with $\mathrm{L}_{\text {count }}$ or $\mathrm{L}_{\text {mean }}$, or do not exhibit any dependence on the strength of the investigated factors. The data suggest that $\mathrm{L}_{\text {mean }}$ mainly depends on the chlorine concentration, whereas $\mathrm{L}_{\text {count }}$ is sensitive to any violations in the conditions of zigzag formation. These violations occur, in particular, at low chlorine concentrations, at protein 
aggregation (but not necessarily at fragmentation), and also in the presence of an excess amount of low molecular weight compounds (ligands) and ions not associated with the protein in the solution. Clarification of the role of these factors in the process of zigzag formation, accounting for other types of patterns and finding more efficient and reproducible methods for obtaining films will be the directions of our further research.

\section{REFERENCES}

1. Yahno T. A. Drops of biological fluids, drying on a solid substrate: the dynamics of morphology, mass, temperature and mechanical properties / T. A. Yahno, V. V. Kazakov, O. A. Sanin, A. G. Sanin, V. G. Yahno // Zh. Tekh. Fiz. - 2010. - Vol. 80. - P. 17-23.

2. Yakhno T. A. Sodium chloride crystallization from drying drops of albumin-salt solutions with different albumin concentrations / T. A. Yakhno // Tech. Phys. - 2015. - Vol. 60. - P. 30-37.

3. Yakhno T. A. Complex Pattern Formation in Sessile Droplets of Protein-Salt Solutions with Low Protein Content. What Substance Fabricates These Patterns? / T. A. Yakhno // Phys. Chem. - 2011. - Vol. 1. P. 10-13.

4. Markevich V. E. Methods of wedge dehydration of biological fluids / V. E. Markevich, E. A. Kirilenko, V. A. Petrashenko, T. U. Zablotskaya, T. A. Bilokon // Morphologia. - 2014. - Vol. 8. - P. 113-117.

5. Gorza F. D. S. Morphological Analysis and Interaction of Chlorophyll and BSA / F. D. S. Gorza, G. C. Pedro, T. F. Trescher, R. J. da Silva, J. R. Silva, N. C. de Souza // BioMed. Res. Int. - 2014. - Vol. 2014. - Article ID 872701. - P. 1-6.

6. Shabalin V. N. The markers of malignant growth in the morphological picture of human biological fluids / V. N. Shabalin, S. N. Shatokhina // Questions of Oncology. - 2010. - Vol. 56, Issue 3. - P. 293-300.

7. Chen R. Blood drop patterns: Formation and applications / R. Chen, L. Zhang, D. Zang, W. Shen // Advances in Colloid and Interface Science. - 2016. - Vol. 231. - P. 1-14.

8. Zablotskaya T. U. Analysis of the main processes and types of structures in the dehydration of biological fluids / T. U. Zablotskaya // Electromech. and energy-saving systems. - 2010. - Vol. 4 (12). - P. 92-95.

9. Elizarov A. I. The method of quantitative evaluation of images with central symmetry on the example of the facies of biological fluids / A. I. Elizarov, T. U. Zablotskaya // Bull. of KSPU. - 2007. - Vol. 1 (42). - Part 1. - P. 8-13.

10. Killeen A. A. Protein Self-Organization Patterns in Dried Serum Reveal Changes in B-Cell Disorders / A. A. Killeen, N. Ossina, R. C. McGlennen, S. Minnerath, J. Borgos, V. Alexandrov, A. Sarvazyan // Mol. Diag. Ther. - 2006. - Vol. 10, Issue 6. - P. 371-380.

11. Kokornaczyk M. Organic wheat quality from a defined Italian field-trial / M. Kokornaczyk, J. Kahl, M. Roose, N. Busscher, A. Ploeger // 16th IFOAM Organic World Congress : book of abstracts, 16-20 June 2008, Modena, Italy. - Mode of access : http://orgprints.org/11732/1/Kokornaczyk_11732_rev.doc.

12. Kokornaczyk M. O. Self-Organized Crystallization Patterns from Evaporating Droplets of Common Wheat Grain Leakages as a Potential Tool for Quality Analysis / M. O. Kokornaczyk, G. Dinelli, I. Marotti, S. Benedettelli, D. Nani, L. Betti // The Scientific World JOURNAL. - 2011. - Vol. 11. - P. 1712-1725.

13. Andersen J.-O. Computerised image analysis of biocrystallograms originating from agricultural products / J.-O. Andersen, C. B. Henriksen, J. Laursen, A. A. Nielsen // Computers and Electronics in Agriculture. 1999. - Vol. 22. - P. 51-69.

14. Busscher N. Standardization of the Biocrystallization Method for Carrot Samples / N. Busscher, J. Kahl, J.-O. Andersen, M. Huber, G. Mergardt, P. Doesburg, M. Paulsen, A. Ploeger // Biol. Agriculture and Horticulture. - 2010. - Vol. 27. - P. 1-23.

15. Kahl J. First tests of standardized biocrystallization on milk and milk products / J. Kahl, N. Busscher, P. Doesburg, G. Mergardt, M. Huber, A. Ploeger // Eur. Food Res. Technol. - 2009. - Vol. 229. P. $175-178$.

16. Patent 110130 Ukraine, IPC12 C09K 19/38, G01N 33/48, G01N 21/956. Method for the estimation of substance effect on biopolymers / G. M. Glibitskiy, D. M. Glibitskiy ; owner is A. Ya. Usikov Institute for Radiophysics and Electronics of the National Academy of Sciences of Ukraine. - № a201312123, appl. 16.10.2013 ; publ. 25.112015 , bull. № 22. -7 p.

17. Patent 111769 Ukraine, IPC12 G01N 21/898, G01N 21/956, C09K 19/38, G01N 33/48. Method for the estimation of substance effect on biopolymers / G. M. Glibitskiy, D. M. Glibitskiy ; owner is A. Ya. Usikov Institute for Radiophysics and Electronics of the National Academy of Sciences of Ukraine. № a201408411, appl. 25.11.2014 ; publ. 10.06.2016, bull. № 11. -8 p.

18. Glibitskiy G. M. Textures on the surface of BSA films with different concentrations of sodium halides and water state in solution / G. M. Glibitskiy, D. M. Glibitskiy, O. A. Gorobchenko, O. T. Nikolov, A. D. Roshal, M. A. Semenov, A. I. Gasan // Nanoscale Res. Lett. - 2015. - Vol. 10, Issue 1. - P. 155-164. 
19. Glibitskiy D. M. Textures of BSA films with iron and copper ions / D. M. Glibitskiy, G. M. Glibitskiy, M. A. Semenov, A. V. Shestopalova // Biophys. Bull. - 2016. - Vol. 35, Issue 1. - P. 21-27.

20. Raz E. New periodic morphologies observed during dendritic growth of ammonium chloride crystals in thin layers / E. Raz, S. G. Lipson, E. Ben-Jacob // J. of Crystal Growth. - 1991. - Vol. 108. - P. 637-646.

21. Mougin K. Complex Pattern Formation in Drying Dispersions / K. Mougin, H. Haidara // Langmuir. - 2002. - Vol. 18. - P. 9566-9569.

22. Gorobchenko O. A. Effect of gamma irradiation of protein solution on the formation of film textures / O. A. Gorobchenko, O. T. Nikolov, D. M. Glibitskiy, A. D. Roshal, A. V. Shestopalova, M. A. Semenov, G. M. Glibitskiy // Nanotechnology and nanomaterials : Int. res. and practice conf. : book of abstracts, 26-29 August 2015, Lviv (Ukraine). - Lviv, 2015. - P. 386.

23. Glibitskiy D. M. Effect of flavin mononucleotide on the texture of BSA films / D. M. Glibitskiy, O. A. Gorobchenko, O. T. Nikolov, A. M. Zibarov, A. D. Roshal, M. A. Semenov, G. M. Glibitskiy // Nanotechnology and nanomaterials : Int. res. and practice conf. : book of abstracts, 24-27 August 2016, Lviv (Ukraine). - Lviv, 2016. - P. 132.

24. Liu X.-Y. Nucleation-limited aggregation of crystallites in fractal growth / X.-Y. Liu, M. Wang, D.-W. Li, C. S. Strom, P. Bennema, N.-B. Ming // J. of Crystal Growth. - 2000. - Vol. 208. - P. 687-695.

25. Mitzenmacher M. A Brief History of Generative Models for Power Law and Lognormal Distributions / M. Mitzenmacher // Internet Mathematics. - 2003. - Vol. 1, No. 2. - P. 226-251.

26. Burr I. W. Cumulative frequency functions / I. W. Burr // Ann. Math. Stat. - 1942. - Vol. 13, Issue 2. P. 215-232.

27. Gusmao F. R. S. de. The generalized inverse Weibull distribution / F. R. S. de Gusmao, E. M. M. Ortega, G. M. Cordeiro // Stat. Papers. - 2011. - Vol. 52. - P. 591-619.

28. Borzova V. A. Kinetics of Thermal Denaturation and Aggregation of Bovine Serum Albumin / V. A. Borzova, K. A. Markossian, N. A. Chebotareva, S. Yu. Kleymenov, N. B. Poliansky, K. O. Muranov, V. A. Stein-Margolina, V. V. Shubin, D. I. Markov, B. I. Kurganov // PLoS One. - 2016. - Vol. 11, Issue 4. - Mode of access : http://journals.plos.org/plosone/article?id=10.1371/journal.pone.0153495.

29. Cho Y. S. Effect of $\gamma$-Irradiation on the Molecular Properties of Bovine Serum Albumin and $\beta$-Lactoglobulin / Y. S. Cho, K. B. Song // J. Biochem. Mol. Biol. - 2000. - Vol. 33, No. 2. - P. 133-137.

30. Mishra K. Protective effect of ferulic acid on ionizing radiation induced damage in bovine serum albumin / K. Mishra, H. Ojha, S. Kallepalli, A. Alok, K. N. Chaudhury // Int. J. Radiat. Res. - 2014. - Vol. 12, Issue 2. - P. 113-121.

31. Akhavan A. Radiation synthesis and characterization of protein stabilized gold nanoparticles / A. Akhavan, H. R. Kalhor, M. Z. Kassaee, N. Sheikh, M. Hassanlou // Chem. Eng. J. - 2010. - Vol. 159. - P. $230-235$.

32. Xu X. Oxygen-dependent oxidation of Fe(II) to Fe(III) and interaction of Fe(III) with bovine serum albumin, leading to a hysteretic effect on the fluorescence of bovine serum albumin / X. Xu, L. Zhang, D. Shen, H. Wu, Q. Liu // J. Fluoresc. - 2008. - Vol. 18, Issue 1. - P. 193-201.

33. Ben-Jacob E. The formation of patterns in non-equilibrium growth / E. Ben-Jacob, P. Garik // Nature. 1990. - Vol. 343. - P. 523-530.

34. Sengupta A. Comparative study of flavins binding with human serum albumin: a fluorometric, thermodynamic, and molecular dynamics approach / A. Sengupta, W. D. Sasikala, A. Mukherjee, P. Hazra // Chemphyschem. - 2012. - Vol. 13, Issue 8. - P. 2142-2153.

35. Zhang Y. Flavin-sensitized photo-oxidation of lysozyme and serum albumin / Y. Zhang, H. Görner // Photochem. Photobiol. - 2009. - Vol. 85, Issue 4. - P. 943-948.

36. Guo X. J. Spectroscopic investigation of the interaction between riboflavin and bovine serum albumin / X. J. Guo, X. D. Sun, S. K. Xu // J. of Mol. Structure. - 2009. - Vol. 931, Issue 1. - P. 55-59.

37. Wang G. Binding mechanism of halide ions to bovine serum albumin and hemoglobin: investigated by ion selective-electrode / G. Wang, W. Tang, X. Hao, C. Yan, Y. Lu // J. Biophys. Chem. - 2011. - Vol. 2 (3). P. 194-201. 